\title{
A multi-criteria decision-making in turning process using the MAIRCA, EAMR, MARCOS and TOPSIS methods: A comparative study
}

\author{
Trung, D.D. ${ }^{a,}{ }^{*}$, Thinh, H.X. ${ }^{b}$ \\ aFaculty of mechanical engineering, Hanoi Univeristy of Industry, Vietnam \\ ${ }^{b}$ Center for mechanical engineering, Hanoi Univeristy of Industry, Vietnam
}

\begin{abstract}
A B S T R A C T
Multi-criteria decision-making is important and it affects the efficiency of a mechanical processing process as well as an operation in general. It is understood as determining the best alternative among many alternatives. In this study, the results of a multi-criteria decision-making study are presented. In which, sixteen experiments on turning process were carried out. The input parameters of the experiments are the cutting speed, the feed speed, and the depth of cut. After conducting the experiments, the surface roughness and the material removal rate (MRR) were determined. To determine which experiment guarantees the minimum surface roughness and maximum MRR simultaneously, four multi-criteria decision-making methods including the MAIRCA, the EAMR, the MARCOS, and the TOPSIS were used. Two methods the Entropy and the MEREC were used to determine the weights for the criteria. The combination of four multi-criteria making decision methods with two determination methods of the weights has created eight ranking solutions for the experiments, which is the novelty of this study. An amazing result was obtained that all eight solutions all determined the same best experiment. From the obtained results, a recommendation was proposed that the multicriteria making decision methods and the weighting methods using in this study can also be used for multi-criteria making decision in other cases, other processes.
\end{abstract}

\section{ARTICLE INFO}

Keywords:

Turning;

Material removal rate (MRR);

Surface roughness;

Multi-criteria decision-making

(MCDM);

Multi Attributive Ideal-Real Com-

parative Analysis (MAIRCA);

Evaluation by an Area-based

Method of Ranking (EAMR);

Measurement of Alternatives and

Ranking according to Compromise

Solution (MARCOS);

Technique for Order of Preference by Similarity to Ideal Solution (TOPSIS);

Entropy;

Method based on the Removal Effects of Criteria (MEREC)

*Corresponding author: doductrung@haui.edu.vn (Trung, D.D.)

Article history:

Received 19 November 2021

Revised 8 December 2021

Accepted 9 December 2021

\section{References}

[1] Medić, N., Anišić, Z., Lalić, B., Marjanović, U., Brezočnik, M. (2019). Hybrid fuzzy multi attribute decision making model for evaluation of advanced digital technologies in manufacturing: Industry 4.0 perspective, Advances in Production Engineering \& Management, Vol. 14, No. 4, 483-493, doi: 10.14743/apem2019.4.343. 
[2] Ko, T.J., Kim, H.S. (2021). Surface integrity and machineability in intermittent hard turning, International Journal of Advanced Manufacturing Technology, Vol. 18, 168-175, doi: 10.1007/s001700170072.

[3] Dich, T.V., Binh, N.T., Dat, N.T., Tiep, N.V., Viet, T.X. (2003). Manufacturing technology, Science and Technics Publishing House, Hanoi, Vietnam.

[4] Özbek, O., Saruhan, H. (2020). The effect of vibration and cutting zone temperature on surface roughness and tool wear in eco-friendly MQL turning of AISI D2, Journal of Materials Research and Technology, Vol. 9, No. 3, 2762-2772, doi: 10.1016/i.jmrt.2020.01.010.

[5] Aggarwal, A., Choudhary, C., Mehrotra, D. (2018). Evaluation of smartphones in Indian market using EDAS, Procedia Computer Science, Vol. 132, 236-243, doi: 10.1016/j.procs.2018.05.193.

[6] Çelikbilek, Y., Tüysüz, F. (2020). An in-depth review of theory of the TOPSIS method: An experimental analysis, Journal of Management Analytics, Vol. 7, No. 2, 281-300, doi: 10.1080/23270012.2020.1748528.

[7] Parida, A.K., Routara, B.C. (2014). Multiresponse optimization of process parameters in turning of GFRP using TOPSIS method, International Scholarly Research Notices, Vol. 2014, Article ID 905828, doi: 10.1155/2014/ 905828.

[8] Singh, A., Datta, S., Mahapatra, S.S. (2011). Application of TOPSIS in the Taguchi method for optimal machining parameter selection, Journal for Manufacturing Science and Production, Vol. 11, 49-60, doi: 10.1515/jmsp.2011. $\underline{002}$.

[9] Maheswara Rao, C., Jagadeeswara Rao, K., Laxmana Rao, K. (2016). Multi-objective optimization of MRR, Ra and $\mathrm{Rz}$ using TOPSIS, International Journal of Engineering Sciences \& Research Technology, Vol. 5, No. 9, 376-384.

[10] Prakash, D.B., Krishnaiah, G., Shankar, N.V.S. (2016). Optimization of process parameters udding AHP and TOPSIS when turning 1040 steel with coated tools, International Journal of Mechanical Engineering and Technology, Vol. 7, No. 6, 483-492.

[11] Khan, A., Maity, K. (2017). Application of MCDM-based TOPSIS method for the selection of optimal process parameter in turning of pure titanium, Benchmarking: An International Journal, Vol. 24, No. 7, 2009-2021, doi: 10.1108/BIJ-01-2016-0004.

[12] Khan, A., Maity, K. (2019). Application potential of combined fuzzy-TOPSIS approach in minimization of surface roughness, cutting force and tool wear during machining of CP-Ti grade II, Soft Computing, Vol. 23, 6667-6678, doi: $10.1007 / \mathrm{s} 00500-018-3322-7$.

[13] Singh, R., Dureja, J.S., Dogra, M., Randhawa, J.S. (2019). Optimization of machining parameters under MQL turning of Ti-6Al-4V alloy with textured tool using multi-attribute decision-making methods, World Journal of Engineering, Vol. 16, No. 5, 648-659, doi: 10.1108/WJE-06-2019-0170.

[14] Mane, S.S., Mulla, A.M. (2020). Relevant optimization method selection in turning of AISI D2 steel using cryogenic cooling, International Journal of Creative Research Thoughts, Vol. 8, No. 10, 803-812.

[15] Rao, S.R., Jeelani, S.A.K., Swamulu, V. (2021). Multi-objective optimization using TOPSIS in turning of Al 6351 alloy, In: Proceedings of Industry 4.0 Technologies in Civil and Mechanical Engineering (ICI4TCME 2020), Vol. 1112, Andhra Pradesh, India, Article No. 1112, doi: 10.1088/1757-899X/1112/1/012010.

[16] Trung, D.D. (2021). Application of TOPSIS an PIV methods for multi - Criteria decision making in hard turning process, Journal of Machine Engineering, Vol. 21, No. 4, 57-71, doi: 10.36897/jme/142599.

[17] Trung, D.D. (2021). A combination method for multi-criteria decision making problem in turning process, Manufacturing Review, Vol. 8, No. 26, Article No. 26, doi: 10.1051/mfreview/2021024.

[18] Pamucar, D.S., Pejcic Tarle, S., Parezanovic, T. (2018). New hybrid multi-criteria decision-making DEMATEL MAIRCA model: Sustainable selection of a location for the development of multimodal logistics centre, Economic Research-Ekonomska Istraživanja Vol. 31, No. 1, 1641-1665, doi: 10.1080/1331677X.2018.1506706.

[19] Aksoy, E. (2021). An analysis on Turkey's merger and acquisition activities: MAIRCA method, Gümüşhane Üniversitesi Sosyal Bilimler Dergisi, Vol. 12, No. 1, 1-11.

[20] Bakir, M., Akan, Ş., Kiraci, K., Karabasevic, D., Stanujkic, D., Popovic, G. (2020). Multiple-criteria approach of the operational performance evalution in the ariline industry: Evidence from the emerging markets, Romanian Journal of Economic Forecasting, Vol. 23, No. 2, 149-172.

[21] Büyüközkan, G., Uztürk, D. (2022). A Novel 2-Tuple SAW-MAIRCA method for partner evaluation for circular economy, In: Kahraman, C., Cebi, S., Cevik Onar, S., Oztaysi, B., Tolga, A.C., Sari, I.U. (eds.), Intelligent and Fuzzy Techniques for Emerging Conditions and Digital Transformation, INFUS 2021, Lecture Notes in Networks and Systems, Vol 307, Springer, Cham.

[22] Kayapinar Kaya, S. (2020). Evaluation of the effect of COVID-19 on countries' sustainable development level: A comparative MCDM framework, Operational Research in Engineering Sciences: Theory and Applications, Vol. 3, No. 3, 101-122, doi: 10.31181/oresta20303101k.

[23] Keshavarz Ghorabaee, M., Zavadskas, E.K., Amiri, M., Antuchevience, J. (2016). Evaluation by an area-based method of ranking interval type-2 fuzzy sets (EAMRIT-2F) for multi-criteria group decision making, Transformations in Business \& Economics, Vol. 15, No. 3, 76-95.

[24] Yazdi, A.K., Hanne, T., Gómez, J.C.O., Alcaraz, J.L.G. (2018). Finding the best third-party logistics in the automobile industry: A hybrid approach, Mathematical Problems in Engineering, Vol. 2018, Article ID 5251261, doi: $10.1155 / 2018 / 5251261$.

[25] Meidute-Kavaliauskiene, I., Ghorbani, S. (2021). Supply chain contract selection in the healthcare industry: A hybrid mcdm method in uncertainty environment, Independent Journal of Management \& Production, Vol. 12, No. 4, 1160-1187, doi: 10.14807/ijmp.v12i4.1356.

[26] Keshavarz Ghorabaee, M., Amiri, M., Zavadskas, E.K., Turskis, Z., Antucheviciene, J. (2017). A new multi-criteria model based on interval type-2 fuzzy sets and EDAS method for supplier evaluation and order allocation with environmental considerations, Computers \& Industrial Engineering, Vol. 112, 156-174, doi: 10.1016/j.cie.2017. 08.017. 
[27] Stević, Ž., Pamučar, D., Puška, A., Chatterjee, P. (2020). Sustainable supplier selection in healthcare industries using a new MCDM method: Measurement alternatives and ranking according to COmpromise solution (MARCOS), Computers \& Industrial Engineering, Vol. 140, Article No. 106231, doi: 10.1016/j.cie.2019.106231.

[28] Tadić, S., Kilibarda, M., Kovač, M., Zečević, S. (2021). The assessment of intermodal transport in countries of the Danube region, International Journal for Traffic and Transport Engineering, Vol. 11, No. 3, 375-391, doi: 10.7708/ ijtte2021.11(3).03.

[29] Stanković, M., Stević, Ž., Das, D.K., Subotić, M., Pamučar, D. (2020). A new fuzzy MARCOS method for road traffic risk analysis, Mathematics, Vol. 8, No. 3, Article No. 457, doi: 10.3390/math8030457.

[30] Ulutaş, A., Karabasevic, D., Popovic, G., Stanujkic, D., Nguyen, P.T., Karaköy, Ç. (2020). Development of a novel integrated CCSD-ITARA-MARCOS decision-making approach for stackers selection in a logistics system, Mathematics, Vol. 8, No. 10, Article No. 1672, doi: 10.3390/math8101672.

[31] Stević, Z., Brković, N. (2020). A novel integrated FUCOM-MARCOS model for evaluation of human resources in a transport company, Logistics, Vol. 4, No. 1, Article No. 4, doi: 10.3390/logistics4010004.

[32] Anysz, H., Nicał, A., Stević, Ž., Grzegorzewski, M., Sikora, K. (2021). Pareto optimal decisions in multi-criteria decision making explained with construction cost cases, Symmetry, Vol. 13, No. 1, Article No. 46, doi: 10.3390/ sym13010046.

[33] Gunantara, N. (2018). A review of multi-objective optimization: Methods and its applications, Cogent Engineering, Vol. 5, No. 1, Article No. 1502242, doi: 10.1080/23311916.2018.1502242.

[34] Roszkowska, E. (2013). Rank ordering criteria weighting methods - A comparative overview, Optimum. Economic Studies, Vol. 5, No. 65, 14-33, doi: 10.15290/0SE.2013.05.65.02.

[35] Keshavarz-Ghorabaee, M., Amiri, M., Zavadskas, E.K., Turskis, Z., Antucheviciene, J. (2021). Determination of objective weights using a new method based on the removal effects of criteria (MEREC), Symmetry, Vol. 13, No. 4, Article No. 525, doi: 10.3390/sym13040525.

[36] Keshavarz-Ghorabaee, M. (2021). Assessment of distribution center locations using a multi-expert subjectiveobjective decision-making approach, Scientific Reports, Vol. 11, Article No. 19461, doi: 10.1038/s41598-02198698-y.

[37] Sabaghian, K., Khamforoosh, K., Ghaderzadeh, A. (2021). Presentation of a new method based on modern multivariate approaches for big data replication in distributed environments, Plos One, Vol. 16, No. 7, Article ID e0254210, doi: 10.1371/journal.pone.0254210.

[38] Lakshmi, V.V.K., Subbaiah, K.V., Kothapalli, A.V., Suresh K. (2020). Parametric optimization while turning Ti-6Al$4 \mathrm{~V}$ alloy in mist-MQCL (green environment) using the DEAR method, Manufacturing Review, Vol. 7, Article No. 38, doi: $10.1051 / \mathrm{mfreview} / 2020034$.

[39] Hwang, C.-L., Lai, Y.-J., Liu, T.-Y. (1993). A new approach for multiple objective decision making, Computers \& Operations Research, Vol. 20, No. 8, 889-899, doi: 10.1016/0305-0548(93)90109-V.

[40] Payal, H., Bharti, P.S., Maheshwari, S., Agarwal, D. (2020). Machining characteristics and parametric optimisation of Inconel 825 during electric discharge machining, Tehnički Vjesnik - Technical Gazette, Vol. 27, No. 3, 761-772, doi: 10.17559/TV-20190214135509.

[41] Trung, D.D., Nguyen, N.-T., Van Duc, D. (2021). Study on multi-objective optimization of the turning process of EN 10503 steel by combination of Taguchi method and Moora technique, EUREKA: Physics and Engineering, Vol. 2021, No. 2, 52-65, doi: 10.21303/2461-4262.2020.001414. 


\title{
Večkriterijsko odločanje $v$ procesu struženja z metodami MAIRCA, EAMR, MARCOS in TOPSIS: Primerjalna študija
}

\author{
Trung, D.D. ${ }^{\mathrm{a},{ }^{*}}$, Thinh, H.X. ${ }^{\mathrm{b}}$
}

aFaculty of mechanical engineering, Hanoi Univeristy of Industry, Vietnam

${ }^{b}$ Center for mechanical engineering, Hanoi Univeristy of Industry, Vietnam

\section{POVZETEK}

Večkriterijsko odločanje je pomembno in vpliva na učinkovitost procesa mehanske obdelave in tudi na ta postopek na splošno. Večkriterijsko odločanje pomeni določanje najboljše alternative med mnogimi alternativami. $\mathrm{V}$ tej študiji so predstavljeni rezultati študije večkriterijskega odločanja. Pri tem je bilo izvedenih šestnajst eksperimentov procesa struženja. Vhodni parametri eksperimentov so bili rezalna hitrost, podajalna hitrost in globina reza. Po izvedbi eksperimentov smo določili površinsko hrapavost in stopnjo odstranjevanja materiala (MRR). Da bi ugotovili, kateri eksperiment hkrati zagotavlja najmanjšo površinsko hrapavost in največjo MRR, so bile uporabljene štiri večkriterijske metode odločanja: MAIRCA, EAMR, MARCOS in TOPSIS. Za določitev uteži za kriterije sta bili uporabljeni dve metodi, entropija in MEREC. Kombinacija štirih večkriterijskih metod odločanja z dvema metodama določanja uteži je ustvarila osem nivojev vrednotenja rešitev eksperimentov, kar je novost te študije. Dosežen je bil izjemen rezultat, saj je vseh osem nivojev vrednotenja potrdilo isti eksperiment kot najboljši. Na podlagi rezultatov je bilo predlagano priporočilo, da se metode večkriterijskega odločanja in metode temeljitega presojanja, uporabljene $\mathrm{v}$ tej študiji, lahko uporabijo tudi za večkriterijske odločitve $\mathrm{v}$ drugih primerih in pri drugih procesih.

\section{PODATKI O ČLANKU}

Ključne besede:

Struženje;

Stopnja odstranjevanja materiala (MRR);

Hrapavost površine;

Večkriterijsko odločanje (MCDM); Primerjalna analiza več atributov idealno-realno (MAIRCA);

Vrednotenje po območni metodi razvrščanja (EAMR);

Merjenje alternativ in razvrščanje glede na kompromisno rešitev (MARCOS);

Tehnika razvrstitev preferenc po podobnosti z idealno rešitvijo (TOPSIS);

Entropija;

Metoda, ki temelji na učinkih odstranitve kriterijev (MEREC)

*Kontaktna oseba: doductrung@haui.edu.vn (Trung, D.D.)

Zgodovina članka:

Prejet 19. novembra 2021

Popravljen 8. decembra 2021

Sprejet 9. decembra 2021

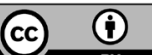

Content from this work may be used under the terms of the Creative Commons Attribution 4.0 International Licence (CC BY 4.0). Any further distribution of this work must maintain attribution to the author(s) and the title of the work, journal citation and DOI. 